石油技術協会誌 第 83 巻 第 2 号 （平成 30 年 3 月） $156 \sim 161$ 頁

Journal of the Japanese Association for Petroleum Technology

Vol. 83, No. 2 (March, 2018) pp. 156 161

\begin{tabular}{l}
\hline 講 演 \\
Lecture \\
\hline
\end{tabular}

地中レーダによる地下探査への AI (機械学習) 利用例*

\author{
山下 善 弘 $^{* *,+}$
}

(Received March 8, 2018 ; accepted March 19, 2018)

\title{
An Application Example of Machine Learning to Shallow Subsurface Exploration using Ground Penetrating Radar
}

Yoshihiro Yamashita

\begin{abstract}
We applied a supervised machine learning method for the purpose of auto detecting cavities under paved roadway from GPR (Ground Penetrating Radar) images. In cavity detection surveys under paved road way, we typically use vehicle-born GPR systems for the necessity to cover wide survey area without any traffic controls. To detect cavity from massive data acquired by vehicle-borne GPR swiftly, skilled-engineers carefully interpret GPR data considering features based on physics of GPR response. Automatic process based on knowledges of skilled-engineers is required, although automatic anomaly detection has not practically realized cause of un-uniform or complex responses from cavities. We applied machine learning methods to detect cavity anomalies using actual GPR data which were acquired on natural occurred cavities as training data. At the verification with actual survey data, our method was able to detect cavitycaused GPR patterns. This will be helpful for analyzer to narrow down cavity responses, meanwhile there were still too many over detections. We think accumulation of labeled GPR data of cavity will also contribute to improvement of our method.
\end{abstract}

Keywords : GPR, cavity detection, machine learning, decision tree learning, kernel-SVM

\section{1.はじめに}

舗装道路における安全安心を確保するための維持管理の 一環として, 道路陥没を未然に防ぐための路面下空洞調査 が計画的に行われている。このような調査では，一般的に 車載型の地中レーダ測定器により 1 日あたり数十キロ以上 といつた広範囲を効率的に測定する。陥没の危険性が高い 空洞箇所などは, このような短時間で大量に取得される データの中からいちはやく検知することが望まれる。舗装 道路構造という比較的均一な中で発生する空洞の地中レー ダによる応答は, ごく典型的な応答を示すものも数多いが, 空洞そのものの形状や周辺土質 - 人工構造物の反応といつ た不規則な要因も加わり複雑な形状を示すものも少なくな い。このような空洞か否かの判断に迷うような空洞反応箇 所を車載レーダのみのデータで漏れなく抽出することは技 術者の経験に頼る部分が大きい。また技術者単独による目 視判定のゆらぎが誤判定の原因とならないよう, 複数人で

\footnotetext{
* 平成 29 年 10 月 24 日, 平成 29 年度秋季講演会「次世代技術への挑戦 -X年後の石油ガス開発に向けて」にて講演 This paper was presented at the 2017 JAPT Autumn Meeting entitled "Challenges to the technologies of the next generation - towards the E\&P Industry after X years" held in Tokyo, Japan, on October 24, 2017.

** 応用地質株式会社 技術本部 OYO Corporation

† Corresponding author : E-Mail : yamashita-yoshi@oyonet.oyo.co.jp
}

同一のデータを解析して結果を統合することで確度を向上 させることも行われる。多くの場合, 経験豊富な技術者へ の負担が集中するため, 自動化による省力化が求められて いる。埋設管や空洞の地中レーダ応答箇所のパターン認識 による自動抽出に関する研究は過去にも例が多いが自動処 理には課題も多い。本講演では, 実際に空洞を確認した箇 所での地中レーダデータをもとに類似箇所を自動抽出する ことを目的とし, 近年, 画像認識などの広範な分野で普及 が進む機械学習の適用を試みた結果について紹介する。

\section{2. 地中レーダによる路面下空洞調査}

道路施設の老朽化や地震に伴う損傷などといつた要因 で, 道路下に空洞が発生し陥没に至ることがある。国土交 通省 ${ }^{1)}$ によれば, 管路施設に起因した道路陥没件数は平 成 27 年度で約 3,300 件に及んでいる。このような背景から, 道路および道路構造物の適切な維持管理の重要性がますま す高まっている。舗装道路管理においては, 例えば直轄国 道では道路パトロールによりわだち掘れやポットホールと いつた路面上での異常を把握するとともに，地下で発生す る空洞の有無を調査するために, おおむね 1 年〜数年程度 に 1 回, 路面下空洞探査を含む調査を実施している。路面 下空洞探査では, 電磁波により道路下の異常を捉える地中 レーダ調査と, 削孔を伴うファイバースコープ調査により 


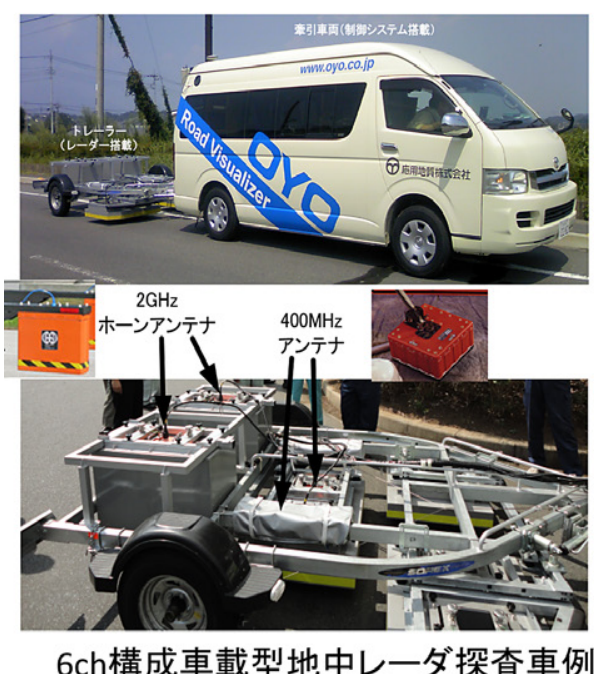

6ch構成車載型地中レーダ探査車例

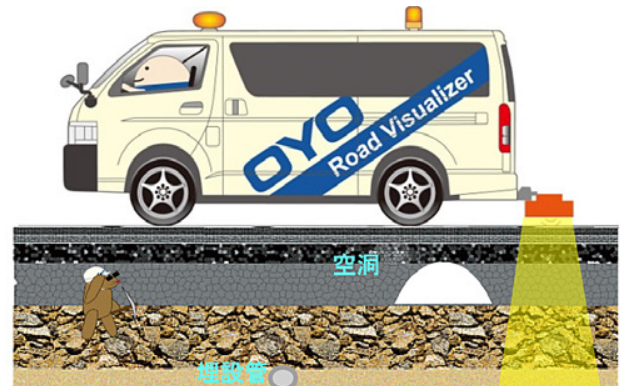

路面下探査車 ロード・ビジュアライザーの概要

【標準探査仕様例】

・地中レーダ探査装置: GSSI社製 SIR-30

（パルス型シングルパス方式、マルチチャンネル）

·探査幅

·探査深度

·測定時最高速度

空洞検出分解能

・データ収録密度

・ポジショニング: RTK-GNSS, 光学デジタル距離計、

ハンドマーク、周辺画像とレーダ記録を同期

図 1 車載型地中レーダシステムの例 ${ }^{4)}$

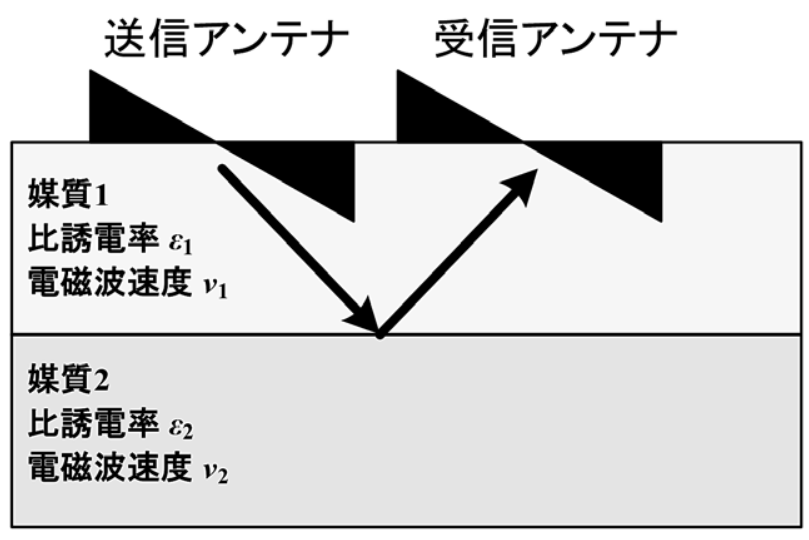

図 2 地中レーダの概念図

空洞の有無を調査し，路面陥没の未然防止を図っている ${ }^{2)}$ 。 路面下空洞探査における地中レーダ調査では，まず一次調 査として交通規制をすることなく広範囲の測定を効率的に 行うために, 地中レーダ機器や測位機器などを搭載した車 載型測定器が利用される。この一次調査において得られた 地中レーダデータより，空洞の可能性がある異常信号箇所 を抽出する。一次調査により抽出された異常信号は，異常 箇所の独立性や規模・深さ，あるいは過年度デー夕がある 場合は経年変化といった異常箇所の個別属性に加えて，周 囲の空洞履歴や舗装構成など総合的に勘案した上で，ハン ディ型地中レーダによる詳細調査の必要性有無について判 定が行われる ${ }^{3)}$ 。図 1 に路面下空洞調査で用いられる車載 型地中レーダシステムの例を示した。図 1 で示した例では 1 日に $50 \mathrm{~km}$ 程度の路線長のデー夕を取得することが可能 である。例示したシステムでは地中レーダアンテナを 6 台
搭載しており, 地中レーダデータの延べ距離では $300 \mathrm{~km}$ 程度のデータが 1 日で取得される。

地中レーダの概念図を図 2 に示した。地中レーダは電磁 波の波動的性質を利用した計測法であり, 電磁波速度の異 なる媒質の境界面からの反射波を計測することで地下構造 を推定する調査手法である。

地中レーダで用いられる $10 \mathrm{MHz}$ より高い周波数領域で は, 電磁波速度は主に比誘電率 $\varepsilon_{r}$ に依存し, 地中での電 磁波速度 $v$ は(1) 式で与えられる。比誘電率の異なる境界 における電磁波の反射の強さを示す度合いを反射係数（ま たは反射率）「と呼び, 図 2 で示したような媒質 1 (比誘 電率が $\varepsilon_{1}$ ) と媒質 2 (比誘電率が $\varepsilon_{2}$ ) の水平 2 層構造の境 界面では(2)式で与えられる。

$$
\begin{aligned}
& v=\frac{3 \times 10^{8}}{\sqrt{\varepsilon_{r}}}(\mathrm{~m} / \mathrm{s})=\frac{30}{\sqrt{\varepsilon_{r}}}(\mathrm{~cm} / \mathrm{ns}) \\
& \Gamma=\frac{\sqrt{\varepsilon_{1}}-\sqrt{\varepsilon_{2}}}{\sqrt{\varepsilon_{1}}+\sqrt{\varepsilon_{2}}}
\end{aligned}
$$

この反射係数の值が大きいほど反射波の信号強度は大きく なり，また反射波形の位相（極性）も反射係数の符号によ って決まる。反射係数が正の場合には反射波は入射した波 形と同位相になり，負の場合は位相が反転する。

舗装道路を対象とした路面下空洞調査の場合, 舗装構造 内部と空洞との比誘電率のコントラストの違いで空洞検知 が可能になる。図 3 に舗装構造内での主な境界面と空洞と の反射係数の模式図を示した。アスファルト舗装道路の構 造は，大きく分割して表層・基層・路盤層の 3 層からなり その下部は路床と呼ばれる。表層・基層部はアスファルト 混合物層などから構成され，比誘電率は経験的に $4.5 \sim 9$ 


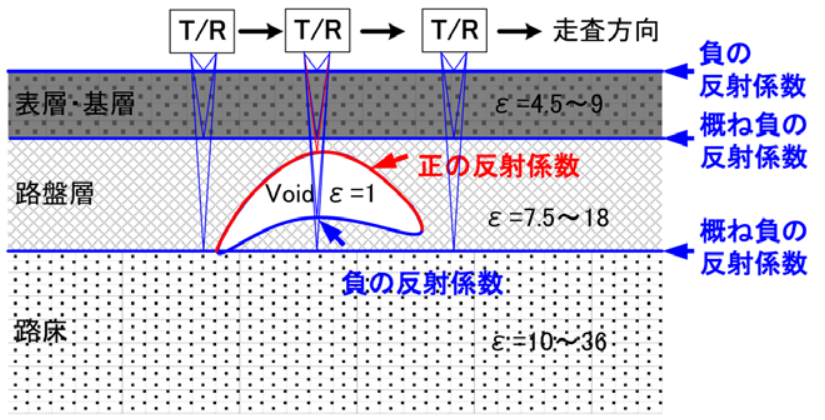

図 3 舗装構造内での空洞と主な境界面での反射係数

程度と 3 層の中では最も低い。路盤層は主に砕石からなり 比誘電率は $7.5 \sim 18$ 程度で中間的な值と想定される。路 床部は路盤下約 $1 \mathrm{~m}$ の部分で改良地盤や自然地盤の一部 から構成される。舗装構造内での各層の境界では経験的に 反射係数が負になることが多い。一方で空気からなる空洞 部分の比誘電率は約 1 であるため空洞上面での反射係数は 周囲に比べて大きくなり，なおかつ正の反射係数を示す。 これが空洞上面からの応答として着目すべき大きな特徵に なる。図 4 には典型的な金属埋設管と空洞でのプロファイ ル図（距離一時間の断面図）の比較例を示した。プロファ イル図は, 各距離・深度における波形振幅值をグレースケー ル画像における輝度值と対応させてラス夕画像としたもの である。空洞や埋設管のように, 走査断面内で孤立して存 在する小さい反射体は点反射体とみなせるため, 反射波に よる応答はプロファイル図上では特徵的な双曲線形状を呈 する。図 4 では, 金属埋設管, 空洞とも応答形状は類似し ているが，金属埋設管では上面の反射面が負の反射係数に なるため空洞の反射波とは逆位相になっていることが分か る。図 4 のプロファイル図は, 応用地質社製の路面下探査 車で取得された記録例で，発信波形をパルス波形（中心周 波数 $400 \mathrm{MHz})$ とするインパルスレーダーを用いている。
距離方向の記録密度は $2.5 \mathrm{~cm}$ 間隔で 1 波形を取得している。

図 4 では比較的典型的な応答例を示したが, 実際にはこ のような明瞭な応答が常に得られるとは限らない。プロ ファイル図における反射応答画像は, 空洞の形状や地盤状 況, 周囲の人工構造物の有無や車載測定時のアンテナと空 洞との平面的な相対位置関係などの要因で複雑な様相を呈 する場合も少なくない。図 5 に比較的不規則な形状をした 実際の空洞確認箇所のプロファイル例（図中, 赤点線枠内） を示した。

一次調査デー夕の解析では, 図 4 や図 5 で示したような プロファイル図上の画像や代表箇所の波形記録を, 隣接 アンテナの応答も考慮しながら目視判定し, さらにデータ 取得時に同時撮影する周辺画像, 埋設物の管理台帳なども 必要に応じて参照しながら空洞・非空洞の判定を行う。本 研究ではこのような大量デー夕処理の省力化・迅速化を目 的として, 教師あり機械学習による空洞記録の自動認識と 識別の適用を試みた。

\section{3. 機械学習手法を用いた地中レーダデータ の自動処理}

機械学習とは一般に, データに含まれる規則性などを見 つけ出し, 類似したものの分類・検知などをコンピュータ により実現するための技術群の総称である。本研究では類 似したパターンを見つけ出す教師あり機械学習手法を用い て, 空洞異常箇所の自動抽出を行った。分類対象となる入 力デー夕とその分類結果である教師データ（ラベル）の対 は学習データと呼ばれるが，ここでは学習データとしてこ れまで技術者の目視判定により空洞による異常信号と判定 され，掘削により実際に空洞と確認された箇所での地中 レーダの実測データを用いた。これと合わせて非空洞箇所 の地中レーダデータも学習データとして用いた。アルゴリ ズム選定においては，実運用をふまえて一般的な PC でも 十分に実行できる高速性を有し，学習データとして利用で きる空洞の実測デー夕数にはある程度制限があることを考

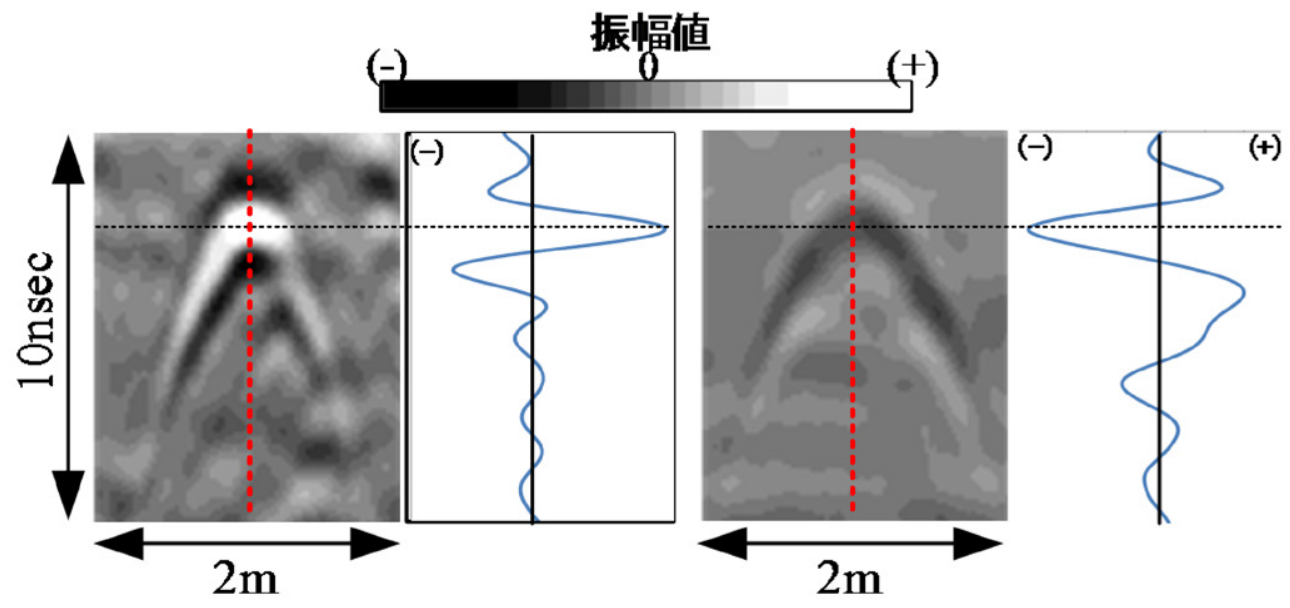

図 4 埋設管による応答（i）と空洞箇所での応答（ii） 


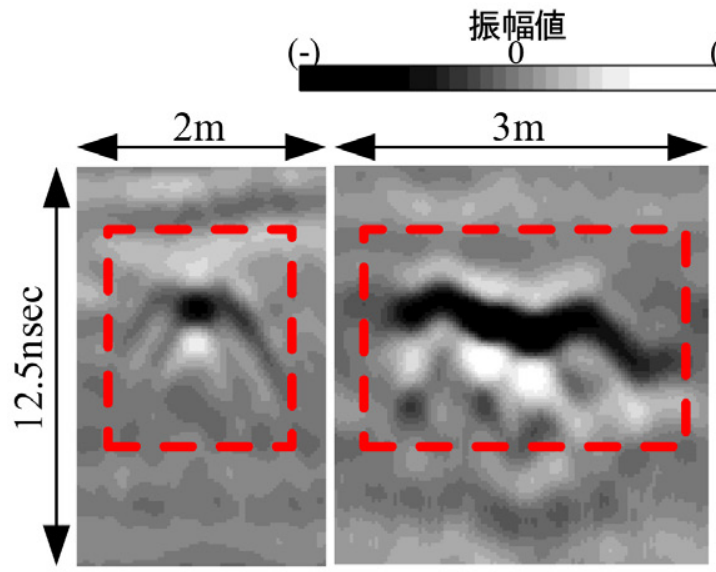

(i)

(ii)

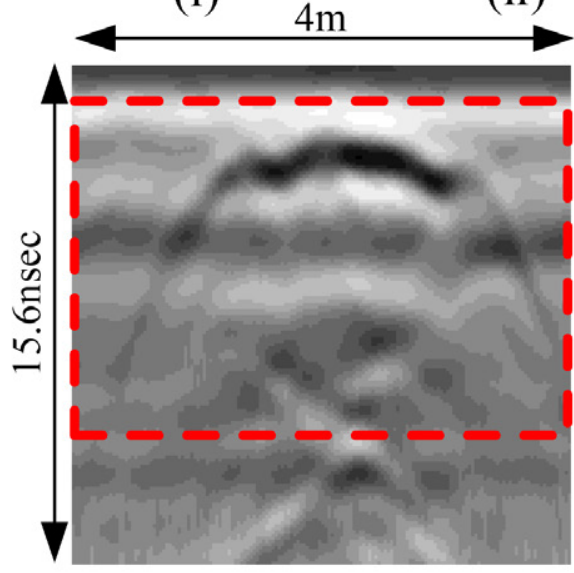

(v)
$(+)$

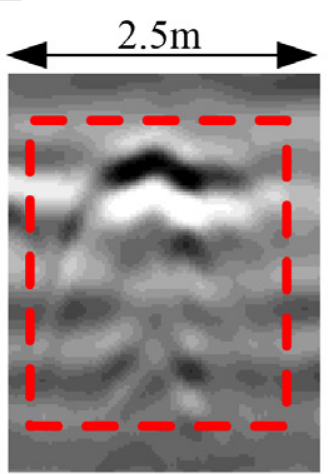

(iii) (iv)
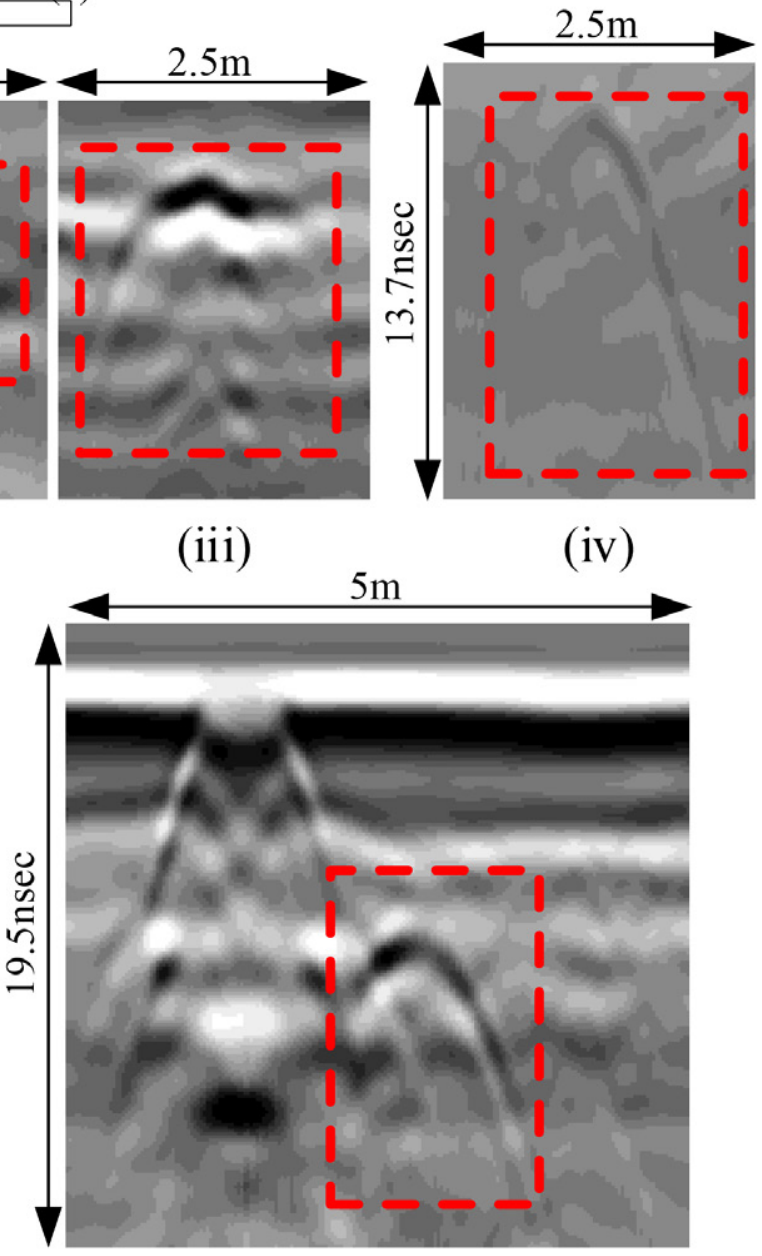

(vi)

図 5 比較的不規則な空洞応答の例

慮した。この中で, 近年盛んに研究されている深層学習に よる手法は, 十分な性能を発揮するためには例えば 100 万 個を超えるような大量の学習データとそのための計算資源 を必要とするため, 本研究の選定アルゴリズムからは除外 した。図 6 に, 本研究で採用した手法の概念図を示した。 本研究での識別プロセスは, 大きく分けて 2 段階からなる。 1 段目の識別器では図 4 や図 5 で示したようなプロファイ ル図でのグレースケール二次元画像とそのラベル（空洞か 非空洞か）を学習データとし, 空洞箇所との類似画像の候 補箇所を全体のデータから抽出する。2段目では，1段目 で抽出された箇所から，典型的な空洞応答を示している箇 所での波形デー夕を利用して空洞であるかどうかの識別を

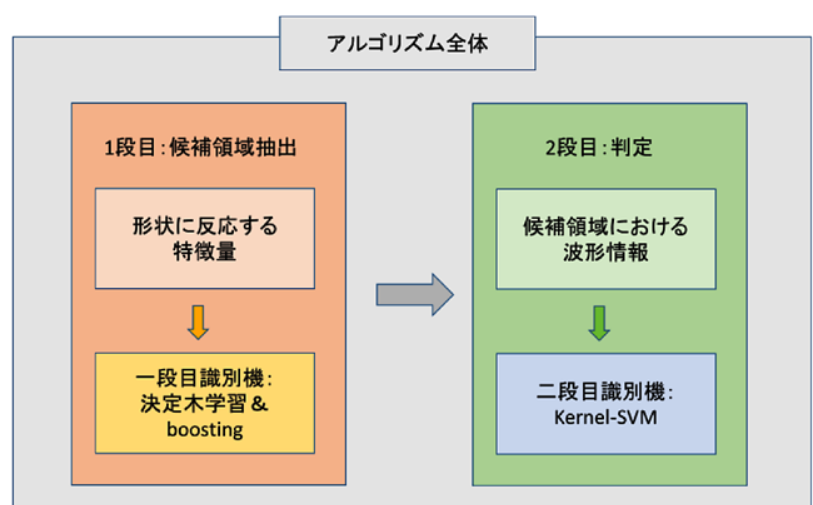

図 6 空洞箇所自動抽出処理の概念図 
行い，最終的に空洞箇所の候補箇所を絞り込む。

1 段目の処理では, 形状に起因する特徵量を画像から抽 出して識別器の入力とした。1段目では長距離の地中レー ダデータ全体に対してサーチを行うので, 特に高速性が要 求される。そこで識別器には決定木学習を用いた。決定木 とはその名のとおりツリー構造を持つ識別器であり, 入力 されたデータはツリー構造におけるノード（分岐点）にお いて特徵量に関わる設定条件に則つて分岐していく。学習 の際には, 学習データのうち同じラベルをもつ入力データ が各ノードでなるべく少数の枝に集中して分岐するように 条件が設定される ${ }^{5)}$ 。さらに決定木学習において，目標ど おり識別できなかつた学習デー夕に対して強い重みをつけ て再度学習を繰り返すブースティングと呼ばれる手法を組 み合わせることで高速性と性能を両立させた。2段目の処 理では, 1 段目で抽出した空洞候補領域の代表的波形を識 別器の入力として空洞・非空洞の識別を行う。ここではさ まざまな種類のデータに対して高い識別性能を有するカー ネルサポートベクターマシン（kernel-SVM）を識別器に用 いた。SVM は学習データの集合を 2 值分類するための境 界を決定する識別器である。SVM では識別境界とそれに 最も近いデータ点との距離を最大にするマージン最大化と 呼ばれる学習を行う。SVM は高次元かつ比較的少ない学 習データに対しても, 学習データ以外の実データに適用し た際の正解率が高い安定した性能を発揮できる特長がある 6)。SVM は決定木学習ほどではないが機械学習手法の中で は比較的高速に実行可能な手法の 1 つであり，本研究では 上述の 2 段構成により高速かつ次章で述べるように比較的 安定したアルゴリズムを実現できた。

\section{4. 走行データによる検証}

本手法による実データに対する空洞箇所の検出性能に関 して検証を行うことを目的として，実際の走行デー夕を用 いて自動解析を実施した結果と，従来どおりの技術者によ る目視判定解析を行い, 削孔とファイバースコープ調査で 空洞確認まで行った結果とを比較した。走行デー夕は前述 の路面下探査車により取得された記録である。なお検証に 用いたデータに含まれる空洞箇所の地中レーダデータは学 習データに含めていない。検証には 2 か所の調査デー夕を
用いて, 確認済みの空洞からの応答と考えられる記録が得 られている箇所が自動解析により抽出された中に含まれて いるかについて主に確認した。

検証結果を表 1 に示した。なお空洞 1 か所につき複数の 地中レーダアンテナで応答が捉えられていることもあるた め, このようなケースはそれらを独立した応答として計数 して比較した。このため空洞箇所数（表 1 中 (1)）が応答 箇所数（表 1 中 (2)）はよりも少なくなつている。検証対 象 A では, 空洞による応答箇所 15 か所のうち 14 か所, 検証対象 B では, 空洞による応答箇所 16 か所のうち 12 か所が自動解析で抽出された異常箇所に含まれる結果と なった。自動解析結果で抽出されなかつた検出対象 1 での 1 か所, 検出対象 2 での 4 か所については, 同一空洞によ ると考えられる応答が近接する別のアンテナでの応答で抽 出できており, 空洞そのものの検出としては抽出漏れのな い結果を得ることができた。一方で, 自動解析により抽出 された異常箇所は, 各アンテナでの $1 \mathrm{~km}$ あたりの平均で 31.6 個〜 42.5 個と, 空洞応答箇所の数と比較して誤検出 が大幅に多い結果となっている。これは, 解析の過程で可 能な限り抽出漏れが出ないようにパラメータなどを設定し た結果と考えている。このため, 本アルゴリズムでの自動 解析結果は解析作業の補助という位置づけで, 自動抽出結 果から手動での絞込作業が必要である。今後, 解析作業の 負担をより軽減させることができる実用的なものにするた めに, 空洞からの応答を漏らさず抽出し, かつ誤検出を減 らすような改良を進める必要がある。

\section{5. まとめ}

本報では, 舗装道路下の路面下空洞を対象とした車載型 地中レーダデータにおいて, 空洞による応答箇所の自動抽 出を行うことを目的として, 画像認識と機械学習手法を用 いた自動解析を試みた結果について報告した。その結果, 削孔により確認されている実際の空洞箇所を漏れなく抽出 することができた。一方で，本手法により自動抽出した異 常箇所数は, 実際の地中レーダによる空洞応答箇所数に比 べてまだ大幅に多く, 実用に供するためには手動での選別 作業が欠かせない。これはできるだけ抽出の漏れが出ない ようにパラメータ設定などを行った結果であり, 作業効率

表 1 実走行デー夕を用いた自動解析の検証結果

\begin{tabular}{|c|c|c|}
\hline & 検証対象 $\mathrm{A}$ & 検証対象 B \\
\hline 走行距離 $(\mathrm{km})$ & 約 $13.3 \mathrm{~km}$ & 約 $17.3 \mathrm{~km}$ \\
\hline チャンネル数（=地中レーダアンテナ数） & 6 & 6 \\
\hline (1) 空洞箇所数 (削孔確認済み) & 8 & 6 \\
\hline $\begin{array}{l}\text { (2) 空洞確認箇所からの応答数 (全アン } \\
\text { テナでの合計) }\end{array}$ & 15 & 16 \\
\hline (3) (2)うち自動抽出できた応答箇所数 & 14 & 12 \\
\hline $\begin{array}{l}\text { (4) (1) のうちいずれかのチャンネルで } \\
\text { 空洞応答箇所を抽出できた空洞数 }\end{array}$ & 8 & 6 \\
\hline $1 \mathrm{~km}$ あたり (1 アンテナ)の自動抽出数 & 31.6 & 42.5 \\
\hline
\end{tabular}


改善のためにはこれらをより精度良く絞り込んでいくこと が重要である。今後, 深層学習などの最新知見を取り入れ たアルゴリズムの改良や, 前処理の最適化などの処理手法 の改善を検討するとともに，地中レーダデータを継続的に 集積・整理し, 優良な学習デー夕を蓄積し学習を重ねるこ とで性能を向上させたいと考えている。

\section{謝 辞}

SOINN 株式会社には地中レーダデータ解析のご協力を 頂いた。ここに記して感謝致します。

$$
\text { 参 考 文 献 }
$$

1）国土交通省: 計画的な改築-維持管理 - 下水道, 国土交 通省ウェブサイト, http://www.mlit.go.jp/mizukokudo/sewerage/crd_sewerage_tk_000135.html（2018 年 3 月閲覧).

2）直轄国道の舗装（路面）に関する保全検討委員会,
2011 ：「路面地下の適切な管理のあり方について」, 国土交通省ウェブサイト, http://www.ktr.mlit.go.jp/ road/shihon/road_shihon00000048.html（2018 年 3 月 閲覧).

3）吉澤幸佑, 2014: 地下レーダによる路面下の空洞探査に ついて, 国土交通省関東地方整備局 平成 26 年度スキ ルアップセミナー, http://www.ktr.mlit.go.jp/soshiki/ soshiki00000092.html (2018 年 3 月閲覧).

4）前川 聡 - 山下善弘 - 村上弘行, 2011：路面下探査車 「ロードビジュアライザー」の開発一概要と適用例一, 応用地質年報, No.30, 81-89.

5) Rokach, L., Maimon, O., 2008 : Data mining with decision trees : theory and applications, World Scientific Pub Co Inc. ISBN 978-9812771711.

6) Cortes, C., Vapnik, V., 1995 : Support-vector networks. $M a-$ chine Learning, 20, 273-297. 